\title{
JOSEPH CONRAD-KORZENIOWSKI, AN ENGLISH WRITER WITH A POLISH SOUL: JOSEPH CONRAD'S POLISH HERITAGE ${ }^{1}$
}

\author{
Joanna Skolik \\ University of Opole
}

\begin{abstract}
The article presents a portrait of Joseph Conrad-Korzeniowski, an English writer with a Polish soul. Conrad - the last Polish Romantic — did not only manage to introduce Polish dreams and longings into English (and Western) literature, but also transformed the Polish experience into a universal one. Writing about exotic, faraway places, he disseminated myths concerning Polish national identity, chivalric tradition and the Polish Eastern Borderland atmosphere and ethos. Conrad, a very demanding writer, never presents ready-made answers, nor does he offer simple solutions to the problems of his protagonists. Moreover, everybody can understand Conrad in their own personal way, for he is perceived as "one of us," no matter who "we" are.
\end{abstract}

Keywords: Joseph Conrad-Korzeniowski, Polish soul, English writer, Polish identity, chivalric tradition, Polish Eastern Borderlands

The interpretative problems related to Conrad's life and letters originated in a lack of proper communication between him, and his readers and critics, who all belonged to different worlds, which — in fact—did not have much in common. When ConradKorzeniowski left Poland and arrived in Marseilles in 1874, he was seventeen, and, as such, his 'soul' (which is defined by Merriam-Webster as "the moral and emotional nature of human beings") must have already been fully formed.

Living his later life between the sea and the shore of England (he joined the British Merchant Marine in 1878, and in 1894 gave up the sea for the land, settling down in the UK), the writer obviously evolved and changed, but the foundation of his personality-i.e., his soul, which was responsible for his charm and heritage, but which also became his curse - had been shaped earlier.

Childhood and adolescence are the most important periods of time for human development; it is a time of growing up and discovering the world through senses,

\footnotetext{
${ }^{1}$ In the article, apart from new ideas, there are a few initially presented in Polish in the article "Joseph Conrad-Korzeniowski, czyli polska dusza w literaturze angielskiej” [in:] Antropologiczno-językowe wizerunki duszy w perspektywie międzykulturowe, vol. 2: Świat widziany oczyma duszy, eds. M. Kapełuś, E. Masłowska and D. Pazio-Wlazłowska, Warszawa: Instytut Slawistyki PAN, 2016, pp. 129-139.
} 
early experiences, and contact with the surroundings. The bonds children form with their parents and family members at the time shape their personalities. The emotional, social and physical development of youngsters has a direct influence on the adults they will become.

Childhood is also a time remembered from the time perspective as carefree and happy, even if marked by traumatic and horrific events, as was Conrad's. In A Personal Record the writer admits:

I did not understand the tragic significance of it all at the time though indeed I remember that doctors also came. [...] for me it seems the very happiest period of my existence. [...] There were other children, too, many of whom are dead [...]. Over all this hangs the oppressive shadow of the great Russian Empire [...]. (A Personal Record, 24)

The young Konradek became acquainted with the Eastern Borderland smells, tastes, sounds, views; he became familiar with the people and the countryside of the Borderlands as well as the emotions and feelings related to them. He was brought up by his parents - ardent patriots and lovers of literature (his father was a poet and translator), thus from a very early age the boy read a lot and got to know Polish Romantics as well as foreign writers (mostly English and French). As an adult, Conrad had all those experiences at the back of his mind. Polish culture and tradition as his own and the one that he absorbed subconsciously as first obviously had the deepest impact on the writer's adult life and letters. As Frederick R. Karl pertinently remarks in his book Joseph Conrad: The Three Lives:

When he left Poland, Conrad could not consciously know he had assimilated the details of his background as images, scenes, attitudes, even characters, which he would project, later, in his fiction. [...] The irreconcilables of his background became the irreconcilables of his fiction. He understood things which no English writer knew, for he had left a land whose heritage had no parallel elsewhere in Europe. [...] For a writer, Conrad's preparation was unique. (Karl, 29)

For this very reason I can hardly agree with Amar Acheraiou, who claims that although Polish scholars - "Najder and his followers"-as he puts it, claim that "Conrad's worldview can only be properly grasped in the light of his Polish "chivalric past', and the romantic values of 'honour, duty, fidelity, friendship' in which Conrad was brought up" (Acheraiou, 46), they "are but two sources among many others." Contrary to Acheraiou's statement that "Najder tends to accord a lion's share to Conrad's Polish cultural and social background" (Acheraiou, 43), I believe that this most prominent Polish Conradian "and his followers" are right in asserting the importance of Conrad's Polish background for his writings. It is true that some ideas, trends, notions and opinions present in Conrad's oeuvres exist also in other cultures and traditions, but Conrad learned them through Polish experience, and his first impressions came to him through the Polish language, tradition and heritage.

Although in 1885 Conrad wrote: "When speaking, writing or thinking in English the word Home always means for me the hospitable shores of Great Britain" ( $C L$ 1:12), he did not in fact become an Englishman. Accordingly, in a letter to Kazimierz Waliszewski (5 $5^{\text {th }}$ December, 1903) the writer says: "Both at sea and on land my 
point of view is English, from which the conclusion should not be drawn that I have become an Englishman. That is not the case. Homo duplex has in my case more than one meaning" $(C P B, 240)$.

Discussing Conrad's message, Czesław Miłosz describes the writer's "Polish political emotionality," claiming that it had been completely formed before he left Poland, and that all new experiences did not change Conrad's views. Thus, Conrad hated Russia (meaning Tsarist autocracy) and revolution. In fact, he was always suspicious of Russian politics and promises, but much attached to the British Empire and the Mediterranean culture as well as western cultural heritage in general (Miłosz, 95).

Realising where he belonged spiritually, Conrad stated:

The immortality of Poland? [...] No one doubts it. English critics — and after all I am an English writer-whenever they speak of me they add that there is in me something incomprehensible, inconceivable, elusive. Only you can grasp this elusiveness, and comprehend what is incomprehensible. That is Polishness. Polishness which I took from Mickiewicz and Słowacki (CUFE, 199).

Conrad, like Prince Roman from his only Polish short story, "was of Polish nationality not so much alive as surviving, which persists in thinking, breathing, speaking, hoping, and suffering in its grave, railed in by a million of bayonets and triple-sealed with the seals of three great empires" ("Prince Roman," 206). He came from a country "which demands to be loved as no other country has ever been loved, with the mournful affection one bears to the unforgotten dead and with the unextinguishable fire of a hopeless passion" ("Prince Roman," 220).

Conrad came from Poland - a faraway and practically nonexistent, partitioned country of the time (divided between imperial Prussia, Austria and Russia), whose citizens could only fall back on their country's past glory and mourn her present state. Conrad as a child lived among Polish Eastern Borderland nobility, who became a repository of the Polish tradition and cultural heritage. Polish Eastern Borderland culture of the nineteenth century, with its emphasis on education and high standards of discipline, had a big influence on Conrad (despite the fact that he did not attend school regularly because of poor health, and largely owed his thorough classical education, first, to private tutors and the efforts of his father, and then, in Cracow, to attendance at St. Anne's Gymnasium).

As an adult, Conrad did not perceive Polish Eastern Borderlands as a geographical or historical region but as a discrete area detached from real territories and ethnic groups, a psychological phenomenon, which is still true about the way many Poles perceive the Borderlands today. In Polish tradition the Eastern Borderlands have been a repository of Polishness; an idea, a myth, a formation living in the collective cultural memory of all of us Poles; an inseparable part of Polish literature and history, film and music, painting and other arts (Konwicki, 79). Thus, for Conrad, Polish Eastern Borderlands were a spectral realm.

In fact, all his life Conrad-Korzeniowski was connected to his fatherland on so many levels that perhaps even the writer himself may not have fully realised the 
extent of his native land's influence on his choices and decisions. Poland was deep in his soul and his heart as something elusive and difficult to define but always true and real. It was a spiritual bond with the country and the people he had remembered from his past and cherished through his memories, as well as those who were still present in his life and those with whom he had been in touch for many years through letters (e.g., his maternal uncle Tadeusz Bobrowski). It was as if he had been living his life in two dimensions: the real one among flesh and blood people, and the spectral one, haunted by the ghosts and shadows of the past.

Conrad was no stranger to a two-dimensional world as he was introduced into it in early childhood. From the very beginning of his life he had not only lived in "the oppressive shadow of the great Russian Empire" (A Personal Record, 34), but also in a shadow of death (he lost his mother at the age of eight, and, at eleven, was orphaned by his father) although his experience of death and mourning was not just personal; it was also national. In the partitioned Poland national mourning was a manifestation of the attitude of Poles towards their motherland, which was "not dead, but not living" either (Derrida \& Stiegler, 42). National mourning was an inherent aspect of the resistance movement against the partitioning powers, which perceived the nonexistent, but still "undead" (qtd. in Luckhurst, 84) Poland as a dangerous enemy, and severely punished every trace, or even the slightest suspicion, of an attempt at opposing the oppressors.

Thus, for Poles, national mourning was not only a sign of personal grief, an expression of the nation and country's suffering, but also a manifestation of patriotism. Polish women dressed in black and wore black jewellery as a mark of this patriotic mourning, but also hope for regaining freedom. Such symbolic clothing and jewellery were also worn to commemorate those who had been killed or exiled to Siberia. Mourning services, which quite frequently turned into national demonstrations, were widely organized. Conrad, as a small child, himself experienced the emotions and feelings related to national mourning and the current political situation of Poland.

When Apollo Korzeniowski-Conrad's father-moved to Warsaw to take part in the resistance movement against Russia, Ewa, his wife, with their son Konrad, at first remained in the Ukraine, from where they joined Apollo a few months later. While separated from her husband, in May and June 1861, Ewa Korzeniowska wrote to him about all the patriotic activities taking place in the Ukraine:

They demand lists of hymns sung in churches and information about where those hymns came from. (41) [...] Otherwise mourning is still observed and all is quiet. (42) [...] Here everything and everybody is plunged in complete silence. Mourning is spreading, no one came to Wrangel's farewell ball, the hymn was sung again on Ascension Day. (46) [...] I have been sewing all day, a mourning frock for Konradek. Everyone is in black here, even the children; our little one has been constantly asking to go into mourning. (CUFE, 51)

Remembering what happened next: Apollo's imprisonment in the Warsaw Citadel, the Korzeniowski's exile to Vologda, and the eventual death of both Konrad's parents back in Poland after their return from, and in effect of, Siberia, the writer's words that "[i]n the courtyard of this Citadel—characteristically for our nation—my childhood 
memories begin," are hardly exaggerated (Najder, Conrad..., 30). Such childhood trauma must have affected Conrad for life. All those events and emotions must have left an indelible imprint on his soul, his mind, and his spirit. But Conrad's childhood memories were not only connected with Warsaw, but, first and foremost, with the Polish Eastern Borderlands where he came from, and Cracow where he lived and learned both with his father and at school, following his mother's death. Thus, all Poland 'contributed to the making of' Conrad, to paraphrase the writer in "Heart of Darkness." As Zdzisław Najder rightly observes: "Indeed, Conrad's early years can be looked on as almost symbolic in the combination of national and personal tragedy" $(C P B, 5)$. For Poland was at that time only a spectre: it did not exist as a country but was still alive in the hearts of Poles. It was a "spectre $[. .$.$] hovering$ between life and death, presence and absence, [and] making established certainties vacillate" (Davies, 56).

Thus, in his books Conrad-Korzeniowski combined the two dimensions (the real and spectral), creating his own world: unique, exceptional, special, annoying, but appealing at the same time. He transposed his past experiences and emotions into the present time, looking for some logical connections between those. Conrad somehow played with time, changing its flow; and, in fact, he changed the course of history, for "History itself is an effect of spectrality. [...] Perhaps one should say, furthermore, that this spectrality belongs to what could be called a history in deferred time, a history in the play of writing, which has the structure [...] of an irreducible distension between the event and its recording" (Derrida \& Stiegler, 46).

Conrad presented his own life from a unique time perspective. In A Personal Record he described and explained his adolescent choices and behavior, writing from the perspective of an adult. Thus, it was his history in "deferred time," carefully re-worked, put in an order, composed. He attempted to show that everything that he had done in the past had its purpose, in this way responding to all accusations of betraying his national identity and language. According to Najder, it was "a splendid piece of personal mythology" (Najder, Conrad..., 104). Conrad wrote about the world which had disappeared a long time before, about people who had passed away and things gone by: about his parents, his childhood, departure from Poland, as if he had been writing about his ghosts, his personal spectres. For, in his works, the writer returned somehow to his past as if endeavouring to "access [all his experiences] again in order to attempt changing them" (Blanco \& Peeren, 12). Cathy Caruth claims that to be traumatized is "to be 'possessed by an image or event' located in the past. $[\ldots]$ Trauma [...] is forever engaged in the quest for an answer, an evanescent truth. Such is the case with ghosts that arrive from the past, seeking to establish an ethical dialogue with the present" (qtd. in Blanco \& Peeren, 12).

A Personal Record is haunted not only by ghosts from Conrad's life but also by the spectres of textuality: his uncle Tadeusz Bobrowski's memoirs (see Najder, Conrad in Perspective, 19-67) and gawęda szlachecka, or a nobility yarn. Thus, in it, the literary content and context appear spectral as well. "Poland Revisited" is the best example of Conrad's work where he combines the two worlds, the two dimensions: the real and the spectral. Those two do not only coexist all the time, but depending 
on the circumstances, one of them prevails over the narrator. While living in the reality of 1914, the writer travelled to Poland not only in space but also in time. $\mathrm{He}$ submerged into the past entirely. However, Poland became for him more real than spectral at that time: "And, after all. It had turned out to be no mirage. [...] Poland then, if erased from the map, yet existed in reality; it was not a mere pays du rêve, where you can travel only in imagination" ("Poland Revisited," 198).

Talking about his journey to Cracow in $1914^{2}$ in "Poland Revisited," Conrad narrates the atmosphere of adventure, which was not the same for all his family members: "Moreover, as we set together in the same railway carriage, they were looking forward to a voyage in space, whereas I felt more and more plainly that what I had started on was a journey in time, into the past" ("Poland Revisited," 199). The writer was visiting his own past, his ghosts and shades surrounding him: "My eyes were turned to the past, not to the future; the past that one cannot suspect and mistrust, the shadowy and unquestionable moral possession the darkest struggles of which wear a halo of glory and peace" ("Poland Revisited," 194).

When in Cracow, Conrad recalled the time spent with his dying father, and again the spectrality of the atmosphere gradually increased:

It was in that old royal and academical city that I ceased to be a child, became a boy, had known the friendships, the admirations, the thoughts and the indignations of that age. It was within those historical walls that I began to understand things, form affections, lay up a store of memories and a fund of sensations with which I was to break violently by throwing myself into an unrelated existence. It was like the experience of another world. [...] and I feared at first that if I ventured bodily in there I would discover that I who have had to do with a good many imaginary lives have been embracing mere shadows in my youth. I feared. But fear in itself may become a fascination. Men have gone, alone and trembling, into graveyards at midnight-just to see what would happen. ("Poland Revisited," 194-195).

In Conrad's eyes Cracow had not changed at all since his childhood days, and here it was again, history in "deferred time," as if the time had stopped. On his nocturnal walk through the city everything looked exactly the same as in his childhood: "I felt so much like a ghost that the discovery that I could remember such material things as the right turn to take and the general direction of the street gave me a moment of wistful surprise" (220).

And it so happened that the words written by Joseph Conrad-Korzeniowskian only son of Polish patriots, educated and bred among and by Polish Eastern Borderland nobility in the spirit of Polish romantic patriotism, chivalric tradition and attachment to the Polish tradition and culture, where the Borderlands became a mythical ideal, who had experienced their boundless expanses and the longing for freedom and independence - were read by people who were strangers to the unique Borderland longings and sensibilities, and who were able to rest assured in their wealth and safety, instead. For, in the nineteenth century Britain was the world's

${ }^{2}$ The Conrads were invited by J. H. Retinger's mother-in-law (in fact the idea came from the Retingers) and Conrad decided to accept the invitation, to visit Poland (still not present on the map of Europe) with his family, despite the political situation. 
most powerful country, and Conrad's English readers were able to submerge in the "material values of wealth and economic progress" $(C P B, 2-3)$ rather than the 'soldierly,' or 'aristocratic' ones looked to by Polish nobility, for their assets were not being confiscated, their families persecuted, and they themselves deprived of their future and hope as was the lot of Poles in their partitioned country. Thus, with Conrad, the British people of the Victorian and Edwardian Eras-successful and privileged - were suddenly exposed to a prose written by an author arriving from a completely different reality, totally alien to their own.

Although Conrad was not a popular writer in the modern understanding of the term, he managed to reach an audience which succumbed to the charm of his words and became fascinated by his exotic, but also elusive, provoking, and sometimes annoying, writing. In his memoirs Jan Perłowski recalls his talk with Kipling, who thus explained English fascination with Conrad:

[...] Conrad attracted English readers by his exotic mentality. In every average Englishman there lurks an emotional complex suppressed by his puritanical culture. Conrad released those forces. His characters, drawn with extreme mastery and acceptable to the English reader, have the temperature of their feelings a degree or so above the English norm. [...] 'how many of Conrad's characters are consumed by one idea or one emotion? Have you noticed the intensity of fear and terror? That man must have gone through nightmares himself.' (CUFE, 162-163)

As asserted by Karl, Conrad's Polish life „did not produce anything tangible, but it informed every aspect of his later years, and became the matrix for his ideas, his attachments, memories and nightmares" (Karl, xiii). Conrad transposed all his childhood and adolescent memories, experience and emotions into his adult texts; however, this was not a direct or simple transposition. For, all his remembrances were modified by years of life at sea and experience of other cultures. Conrad himself had a unique chance of being at once "the Other" and "one of us." As "one of us," he was a white European, a seaman, a member of a crew, which, because often quite "international" on British ships at the time, was mostly identifiable by profession; as "the other," Conrad was "our guest," as Virginia Woolf called him (qtd. in Najder, A Life, 573), and a man "without [...] country or language [who] may be thought to have found a new patriotism for himself in the sea. [Whose] vision of men [...] is the vision of a cosmopolitan, of a homeless person" (Robert Lynd, qtd. in Sherry, 211). As "the Other" who wanted to become "one of us"-an English man of lettersConrad had to face British writers and critics, and to prove his talents and skills. As both "one of us" and "the Other," he understood both sides: "us" and "them." In the words of Józef Tischner:

At the start of the origin of awareness of the self lies the presence of you, and perhaps even the presence of a more general we. Only in dialogue, in argument, in opposition [...] is awareness of my self created, as a self-contained being, separate from another. I know that I am, because I know another is. (qtd. in Kapuściński, 67-68)

Thus, Joseph Conrad-Korzeniowski represents the philosophy of dialogue which "is the movement, orientation or trend that tries to address the issues of man-the Self, and extremely crucially, his relations with another person, with the Other" 
(Kapuściński, 68). Aware of his "otherness" in the UK, or in Marseilles, Conrad likewise realises that when in the Belgian Congo, or in Malaysia. Although accused of racism and misogyny, the writer is in fact a humanist. In "Heart of Darkness," Marlow thinks of and looks at the local people in a completely different way than most contemporary Europeans. He sees human beings in the natives and tries to look for some means of communication with them, thus trying to establish a dialogue with the Other.

Conrad wrote directly about Poland and Poles only a few times: in "Autocracy and War," "A Personal Record," "Prince Roman," "Political Memorandum," "Poland Revisited," "A Note on the Polish Problem," and "The Crime of Partition." However, the spirit, the soul of the Borderlands, and Poland, appears quite frequently in his works. I aim at marking those Polish traces in his works, which are not so evident, or obvious. Let me have a brief look at the Polish spectrality of his texts.

In "A Personal Record" Conrad writes about his mother in a straightforward way, introducing into English and world literature the only description of an exemplary Polish Mother: a proud, wise, and noble woman; an ardent patriot, devoted to her family, suffering hardships without complaint. However, many of Conrad's female protagonists possess not only his mother's but also other typical Borderland women's features. For a Polish Mother, a Borderland woman was a paragon of virtue, a guardian of tradition and Polishness. Conrad himself claims that the role model for his Nostromo heroine Antonia Avellanos - an ardent patriot and idealist-was his youthful love:

How we, a band of tallish schoolboys, [...] how we used to look up to that girl just out of the schoolroom herself, as the standard-bearer of a faith to which we all were born but which she alone knew how to hold aloft with an unflinching hope! She had perhaps more glow and less serenity in her soul than Antonia, but she was an uncompromising Puritan of patriotism with no taint of the slightest worldliness in her thoughts. ("Author's Note” to Nostromo, xiv)

There are more Conrad heroines who originated in Polish Romantic literature. Among those are: Mrs. Haldin, Nathalie Haldin, and Tekla from Under Western Eyes; Mrs. Gould from Nostromo, and Lena from Victory, to name but a few.

Conrad's attitude to women also has its roots in his family background and Polish Romantic literature: his parents were real partners and they loved and respected each other. Women in the Polish Romantic tradition were not only beautiful but also stouthearted, capable of sacrifice for, and protection of, their loved ones at all costs. Thus Conrad appreciates and admires women, and can even be called a women's advocate for he respects women's right to decide about their own fate, to live as they wish, or, when in need, to be protected and helped, Jewel (Lord Jim), Lena (Victory), Herman's niece ("Falk"), Winnie Verloc (Secret Agent), Mrs. Hervey ("The Return"), Flora and Mrs. Fyne (Chance), Arlette (The Rover), Kurtz's Intended ("Heart of Darkness") being the cases in point.

When Conrad wrote about honour, he also thought about the issue in a "Polish way." As Najder claims: 
It is evident that the idea of honour was very important for Conrad as a person and stands at the heart of ethical problems that he raised in his books. [...] When Conrad deals with honour in its simple form, as in "The Duel," Chance, or The Rescue, there is little chance for misinterpretation. But whenever the problems raised become more intricate and a deeper comprehension of the whole ethos of which honour forms the centre is required confusion arises, for instance in interpretations of the final part of Lord Jim, or of the predicament of Nostromo. (Najder, Conrad..., 15)

When writing about exotic, faraway places Conrad disseminates myths concerning Polish national identity, chivalric tradition, Eastern Borderland atmosphere of a Paradise lost, or an Arcadia destroyed, granting those myths an aura of universality. The code of chivalry, the ethos of Polish nobility, the magic of the Borderland countryside, all those longings and memories, are to be found in Conrad's Malaysian islands and the province of Sulaco, in Brussels and London, as well as in many other places described in his works. Although not always easily identifiable, they are present in all his books: "Those who read me know my conviction that the world, the temporal world, rests on a few very simple ideas, so simple that they must be as old as the hills. It rests notably, among the others, on the idea of Fidelity" ("A Familiar Preface" to "A Personal Record," xix).

Conrad - the last Polish Romantic - has introduced into Western literature not only Polish dilemmas and doubts, but also dreams and longings. He transformed his Polish experience into a universal one. Thanks to this universality, the elusiveness of his art is inspiring (he is "an inspired man" though, luckily, not in the manner of Peter Ivanovitch). Conrad's works can be interpreted from various positions (highbrow and lowbrow), and on many different levels as well as and in many, often absolutely contradictory, ways. For some, he is a humanist, for others "a bloody racist" or a misogynist, or a chivalric women's advocate. Thus he is being read afresh all the time, inspiring new generations of artists from different areas of art: literature, film, theatre, and music. Through their adaptations of his fiction, film and theatre directors, musicians and composers, etc., continue Conrad's creation.

Conrad is very demanding as a writer. He does not present ready-made answers nor does he offer simple solutions to the problems of his protagonists. Conrad's readers must be very alert and ready to identify all the suggestions hidden in his texts, in other words, they "ought to know enough"3 (CL 2: 283-284) to be able to follow them. Conrad says: "My task which I am trying to achieve is, by the power of the written word, to make you hear, to make you feel - it is, before all, to make you see. Thatand no more, and it is everything" (Preface to The Nigger of the 'Narcissus,' $\mathrm{x}$ ). Thus, the readers should not only perceive Conrad's world with their own eyes, but also understand it. And everybody can understand Conrad in his or her personal way, for Conrad is perceived by many as "one of us," no matter who "we" are.

${ }^{3}$ J. Conrad to William Blackwood, $19^{\text {th }}$ July, 1900. 


\section{WORKS CITED}

Acheraïou, Amar. Joseph Conrad and the Reader: Questioning Modern Theories of Narrative and Readership. New York: Palgrave Macmillan, 2009.

Conrad, Joseph. “Author's Note”. In idem. Nostromo. London: J. M. Dent \& Sons, Ltd., 1950. . A Personal Record: The Mirror of the Sea and A Personal Record. London: J. M. Dent \& Sons Ltd., 1946. i-138. . The Collected Letters of Joseph Conrad. Vols. 1 \& 2. Eds. F. R. Karl and L. Davies. Cambridge: Cambridge University Press, 1983, 1990. . "Poland Revisited". In idem. Notes on Life and Letters. London and Toronto: J. M. Dent \& Sons Ltd., 1921. 189-231. "Prince Roman". In idem. Selected Short Stories. Ed. K. Carabine. Ware: Wordsworth Editions Limited, 1997. 206-223.

Blanco, María del Pilar, Peeren, Esther, eds. "Introduction: Conceptualizing Spectralities". In The Spectralities Reader: Ghosts and Haunting in Contemporary Cultural Theory. New York and London: Bloomsbury Academic, 2013. 1-27.

Busza, Andrzej. "Conrad's Polish Literary Background and Some Illustrations of the Influence of Polish Literature on His Work". Antemurale (Rome) 10 (1966): 109-255.

1980. 1-23.

Davies, Colin. "État Présent: Hauntology, Spectres and Phantoms". In The Spectralities Reader: Ghosts and Haunting in Contemporary Cultural Theory. New York and London: Bloomsbury Academic, 2013. 53-60.

Derrida, Jacques, Stiegler, Bernard. "Spectrographies". In The Spectralities Reader: Ghosts and Haunting in Contemporary Cultural Theory. New York and London: Bloomsbury Academic, 2013. 37-51.

Kapuściński, Ryszard. The Other. Transl. A. Lloyd-Jones. London and New York: Verso, 2008.

Karl, Frederick, R. Joseph Conrad: The Three Lives. London: Faber and Faber, 1979.

Najder, Zdzisław, ed. Conrad's Polish Background: Letters to and from Polish Friends. Transl. H. Carroll-Najder. Oxford: Oxford University Press, 1964. , ed. Conrad Under Familial Eyes. Trans. H. Carroll-Najder. Cambridge: Cambridge University Press, 1983.

. Conrad in Perspective: Essays on Art and Fidelity. Cambridge: Cambridge University Press, 1997. . Joseph Conrad: A Life. Transl. H. Najder. Rochester, NY: Camden House, 2007.

Sherry, Norman, ed. Conrad: The Critical Heritage. London and Boston: Routledge \& Kegan Paul, 1973.

Kaniecki, Przemysław, Konwicki, Tadeusz. Nasze histerie, nasze nadzieje. Spotkania z Tadeuszem Konwickim. Warszawa: Iskry, 2013.

Merriam-Webster, https://www.merriam-webster.com/dictionary/soul.

Miłosz, Czesław. "Stereotyp u Conrada". In Conrad żywy. Ed. W. Tarnawski. London: B. Świderski, 1957. 92-99.

Skolik, Joanna. "Joseph Conrad-Korzeniowski, czyli polska dusza w literaturze angielskiej”. In Antropologiczno-językowe wizerunki duszy w perspektywie międzykulturowej. Vol. 2: Świat oczyma duszy. Eds. M. Kapełuś, E. Masłowska and D. Pazio-Wlazłowska. Warszawa: Instytut Slawistyki PAN, 2016. 129-139. 